\title{
Interaction of Gram-Positive and Gram-Negative Bacteria with Ceramic Nanomaterials Obtained by Combustion Synthesis - Adsorption and Cytotoxicity Studies
}

\author{
ANDRZEJ BORKOWSKI ${ }^{1}$, FILIP OWCZAREK ${ }^{1}$, MATEUSZ SZALA ${ }^{2}$ and MAREK SELWET ${ }^{3 *}$ \\ ${ }^{1}$ Faculty of Geology, University of Warsaw, Warsaw, Poland \\ ${ }^{2}$ Faculty of Advanced Technologies and Chemistry, Military University of Technology, Warsaw, Poland \\ ${ }^{3}$ Department of General and Environmental Microbiology, Poznan University of Life Sciences, \\ Poznan, Poland
}

Submitted 22 June 2015, revised 3 November 2015, accepted 16 November 2015

\begin{abstract}
This paper presents the interactions of Gram-positive (Staphylococcus aureus) and Gram-negative (Pseudomonas putida) bacteria with ceramic materials obtained by combustion synthesis. These studies were conducted based on an analysis of the adsorption of bacteria onto aggregates of ceramic materials in an aqueous suspension. The materials used in the studies were of a nanostructured nature and consisted mainly of carbides: silicon carbide ( $\mathrm{SiC}$ ) in the form of nanofibers (NFs) and nanorods (NRs), titanium carbide, and graphite, which can also be formed by combustion synthesis. Micrometric $\mathrm{SiC}$ was used as a reference material. Gram-positive bacteria adsorbed more strongly to these materials. It seems that both the point of zero charge value and the texture of the ceramic material affected the bacterial adsorption process. Additionally, the viability of bacteria adsorbed onto aggregates of the materials decreased. Generally, P. putida cells were more sensitive to the nanomaterials than S. aureus cells. The maximum loss of viability was noted in the case of bacteria adsorbed onto NRSiC and NFSiC aggregates.
\end{abstract}

Ke y words: Pseudomonas putida, Staphylococcus aureus, adsorption, ceramic nanomaterials, loss of viability

\section{Introduction}

The growing interest in nanostructured materials involves their potential practical use. In this regard, nanostructured materials built from chemically inert and thermally stable carbides, such as silicon carbide $(\mathrm{SiC})$ or titanium carbide $(\mathrm{TiC})$, are particularly important. Recent studies show that nanostructures of silicon and titanium carbides can be obtained via self-propagating combustion synthesis (Huczko et al., 2005; Cudziło et al., 2007). In this process, not only carbide, but also carbon materials such as nanostructured graphite forms, can be produced. Possible applications of such materials include their use in various kinds of filters that would retain microorganisms and, due to their cytotoxic properties, inhibit the growth of microorganisms and biofilms on their surface. Therefore, such filters can be free from the disadvantages of filters based on activated carbon. The available research shows that nanostructured materials could be used in wastewater treatment (Farre et al., 2009; Reddy et al., 2010;
Joseph et al., 2012). Additionally, it has demonstrated the possibility of the adsorption of bacteria onto surfaces of various kinds of ceramic and nanostructured materials. Nanostructured materials may also exhibit strong antibacterial properties, but studies on the interaction between nanostructured carbides and bacteria are still limited. A significant number of studies have been devoted to examining the interactions between bacteria and nanostructured carbon materials, such as single-walled and multi-walled carbon nanotubes, graphene, and fullerenes (Lyon et al., 2006; Kang et al., 2007; 2008a; 2008b; Akhavan and Ghaderi, 2010), as well as modified carbonaceous materials containing metals such as zinc (Yamamoto et al., 2001). Some of these studies are also related to the adsorption of bacteria onto the surface of such materials. This is an important aspect of the research that involves the potential applications of these methods for microbiological water treatment (Rivera-Utrilla et al., 2001; Savage and Diallo, 2005; Li etal., 2008; Qu etal., 2013; Hossain et al., 2014). Similar investigations have focused not only on

\footnotetext{
* Corresponding author: M. Selwet, Department of General and Environmental Microbiology, Poznan University of Life Sciences, Poznan, Poland; e-mail: marek.selwet@gmail.com
} 
nanostructured materials, but also on the biogeochemical interactions between minerals and bacteria, which are associated with biofouling, microbial corrosion, weathering, and mechanisms of biofilm formation (Yee et al., 2000; Rong et al., 2008). In this context, studies have shown the possibility of adsorbing Gram-positive and Gram-negative bacteria to minerals such as quartz, corundum, and iron-containing minerals. The adsorption of bacteria to clay minerals was also studied (Jiang et al., 2007), although it was difficult to separate the bacteria and mineral particles. Similar difficulties may arise when examining the adsorption of bacteria onto aggregates of nanostructures in aqueous suspensions, but the appropriate use of reagents that increase the density of the aqueous environment allows the separation and measurement of unadsorbed bacteria (Jiang et al., 2007). Some of the carbides seem to be completely inert in their interactions with living cells, but in the nanostructured form, they can interact with cells like other nanomaterials. Based on the literature, two basic mechanisms of such interactions can be described: mechanical cell damage and oxidative stress caused by the presence of highly reactive chemical species (e.g., free radicals) on the surface of nanostructures (Cadet et al., 1999; Fenoglio et al., 2006; Barillet et al., 2010). The investigations conducted by Szala and Borkowski (2014) showed a significant toxicity of nanofibers and nanorods of $\mathrm{SiC}$ (NFSiC and $\mathrm{NRSiC}$, respectively) toward Pseudomonas putida bacteria. In these experiments, mechanical damage to cells, a reduction in dehydrogenase activity, and a decrease in $\mathrm{CO}_{2}$ production were found in the bacterial cultures as a result of the antibacterial activity of nanostructured SiC.

The aim of the present studies was to investigate the interaction between bacteria and ceramic materials obtained by self-propagating high temperature synthesis (SHS). Similar results concerning P. putida adsorption onto nanofibers and nanorods of $\mathrm{SiC}$ were presented previously (Borkowski et al., 2015). In this work, we included a part of repeated investigations in order to compare with the results of bacteria adsorption onto the other ceramic materials and to conduct the viability experiment. The materials used were nanostructured carbides, such as nanofibers $\mathrm{SiC}$ (NFSiC), nanorods $\mathrm{SiC}$ (NRSiC) and $\mathrm{TiC}$, but also included graphite and a mixture of graphite and $\mathrm{TiC}(\mathrm{TiC} / \mathrm{C})$, which can be synthesised via the SHS route. The studies mainly involved the adsorption process and the viability of Gram-positive and Gram-negative bacteria on the surface of aggregations of the aforementioned materials in aqueous suspensions. These studies were conducted in relation to standard micrometric $\mathrm{SiC}(\mu \mathrm{mSiC})$, which was used as reference material to verify the hypothesis that the adsorption process and the loss of cell viability depend on the textures of the materials.

\section{Experimental}

\section{Materials and Methods}

$\mu \mathrm{mSiC}$ powder was purchased from Sigma-Aldrich (St. Louis, MO, USA) and used without purification. Carbon monofluoride (CF), poly(tetrafluoroethene) (PTFE), hexachloroethane $\left(\mathrm{C}_{2} \mathrm{Cl}_{6}\right), \mathrm{CaSi}_{2}$, and TiSi were purchased from commercial sources (SigmaAldrich and Alfa Aesar, Ward Hill, MA, USA). Ceramic nanomaterials were produced by combustion synthesis (SHS) in a stainless steel autoclave according to our previously published methods. NFSiC were synthesized by the SHS method using a PTFE/CaSi ${ }_{2}$ system (Huczko et al., 2005). NRSiC were produced during the combustion of the CF/AlSi system (Szala and Borkowski, 2014). Nanometric TiC was synthesized using a CF/ TiSi system, and a mixture of titanium carbide with graphite $(\mathrm{TiC} / \mathrm{C})$ was obtained in using a TiSi $/ \mathrm{C}_{2} \mathrm{Cl}_{6}$ system (Szala, 2010). Graphite nanoparticles were synthesized during the combustion of a $\mathrm{CF} / \mathrm{Al}$ mixture (Cudziło et al., 2007). The point of zero charge (PZC) of the investigated materials was analyzed according previously described potentiometric titration methods (van der Wal et al., 1997; Bourikas et al., 2003; Borkowski et al., 2015). Scanning electron microscopy (SEM) images of the investigated materials are presented in Fig. 1. An example of mass titration curves is shown in Fig. 2. The PZC values of the investigated materials are presented in Table I.

Microorganisms and media. Strains of P. putida and Staphylococcus aureus (ATCC6538) were obtained from our own collection of pure strains of microorganisms (Geomicrobiology Laboratory, Faculty of Geology, University of Warsaw). Bacteria belonging to the genus Pseudomonas are the most commonly investigated Gram-negative microorganisms in relation to adsorption onto different materials. Similarly, S. aureus together with Bacillus subtilis are considered typical Gram-positive bacteria. (Yamamoto et al., 2001; Ams et al., 2004; Jiang et al., 2007; Rong et al., 2008). Taxonomic affiliation was confirmed by sequence analysis of the 16S rRNA gene. The bacteria were cultivated in both liquid and solid nutrient media ( $\mathrm{pH} 7.5$ ) comprising the following $\left(\mathrm{g} \mathrm{L}^{-1}\right)$ : glucose, 10; peptone, 5; yeast extract, 2; $\mathrm{NaCl}, 4$; and agar (in the case of solid medium), 20. The media were autoclaved at $121^{\circ} \mathrm{C}$ for $15 \mathrm{~min}$.

Protein measurements. To analyze the number of adsorbed bacteria without using the cultivation method, the correlation between protein content and bacterial counts was plotted for P. putida and S. aureus separately. The protein measurement was conducted according to Borkowski et al. (2015).

Adsorption tests. Adsorption tests were designed based on previous work (Jiang et al., 2007) with impor- 
tant modifications published by Borkowski et al. (2015). Adsorption tests were conducted in phosphate buffer $(1 / 15 \mathrm{M})$ at three $\mathrm{pH}$ values: 3.0, 6.8, and 9.0. The $\mathrm{pH}$ was adjusted with small aliquots of $\mathrm{NaOH}$ (approximately $20 \mu \mathrm{l}, 6 \mathrm{M}$ ) or $\mathrm{H}_{3} \mathrm{PO}_{4}$ (approximately $20 \mu \mathrm{l}$, $80 \%)$. Adsorption was measured as follows. Twenty milligrams of investigated nanomaterials or $50 \mathrm{mg}$ of $\mu \mathrm{mSiC}$ were mixed with $2 \mathrm{ml}$ of buffer containing $10^{\circ}$ P. putida or S. aureus cells $\mathrm{ml}^{-1}$. Next, the suspensions were shaken $(120 \mathrm{rpm})$ for $3 \mathrm{~h}$ at $25^{\circ} \mathrm{C}$. After mixing, $1 \mathrm{ml}$ of the suspension was placed into an Eppendorf tube and $0.3 \mathrm{ml}$ of sucrose (60\%) was added. Then, the mixture was centrifuged for $2 \mathrm{~min}$ at $4000 \mathrm{rpm}$ (2600 g) to remove the solid materials. A total of $1 \mathrm{ml}$ of supernatant containing unadsorbed bacteria was used to determine the protein concentration as described above. The number of adsorbed bacteria was calculated from the difference between the number of bacteria in suspension before and after adsorption. The adsorption tests were conducted in triplicate. The parameters of the Langmuir and Freundlich isotherms were calculated for the adsorption at $\mathrm{pH}$ 6.7. The adsorption was measured in the same way as described above in buffer containing $0-10 \times 10^{8}$ P. putida or S. aureus cells $\mathrm{ml}^{-1}$. The Langmuir isotherm is described by the following equation:

$$
n=\frac{A_{m} \cdot K_{L} \cdot C_{e q}}{1+K_{L} \cdot C_{e q}}
$$

where $n$ is the amount of adsorbed bacteria $\left(\times 10^{10}\right.$ cells $\left.\mathrm{g}^{1}\right), A_{\mathrm{m}}$ is the maximal number of adsorbed bacteria $\left(\times 10^{10}\right.$ cells $\left.\mathrm{g}^{-1}\right), K_{\mathrm{L}}$ is the Langmuir constant, and $\mathrm{C}_{\mathrm{eq}}$ is the equilibrium bacterial concentration $\left(\times 10^{8}\right.$ cells $\left.\mathrm{g}^{1}\right)$.

The Freundlich isotherm is described by the equation:

$$
n=K_{\mathrm{F}} \cdot C_{\mathrm{eq}}{ }^{b}
$$

where $K_{\mathrm{F}}$ is the constant of the isotherm, $b$ is a parameter that has value in the range $<0 ; 1>$, and $n$ and $C_{\mathrm{eq}}$ are as described for the Langmuir isotherm.

To fit the experimental data to the Langmuir model, a statistical spreadsheet (Statistica 10, StatSoft. Inc. Tulsa, OK, USA) was applied using the method of least squares for nonlinear models, while the Freundlich model was fitted to the experimental data using the linearized isotherm:

$$
\log n=b \cdot \log C_{\text {eq }}+\log K_{\mathrm{F}}
$$

Measurement of the affinity of bacteria for the investigated materials. The adsorption of bacteria onto the surface of the tested materials does not always allow one to use the Langmuir isotherm parameters to evaluate the affinity of bacteria for aggregates of nanostructures in aqueous suspensions. Therefore, it was decided to first measure the affinity by approximating the first three data points with a second-degree polynomial function to give:

$$
n=A \cdot C_{\mathrm{eq}}{ }^{2}+B \cdot C_{\mathrm{eq}}+C
$$

where $n$ is the amount of adsorbed bacteria $\left(\times 10^{10}\right.$ cells $\left.\mathrm{g}^{-1}\right), \mathrm{C}_{\mathrm{eq}}$ is the equilibrium bacterial concentration $\left(\times 10^{8}\right.$ cells $\left.\mathrm{g}^{-1}\right)$, and $\mathrm{A}, \mathrm{B}$ and $\mathrm{C}$ are the parameters of the polynomial.

Next, the differentiation of the obtained function was taken at the point $\mathrm{C}_{\mathrm{eq}}=0$, and this value was considered to be a constant for bacterial adsorption, which may be regarded as a measure of affinity:

$$
\frac{d n}{d C_{\mathrm{eq}}(0)}=B=K_{\mathrm{ads}}
$$

where $n$ is the amount of adsorbed bacteria $\left(\times 10^{10}\right.$ cells $\left.\mathrm{g}^{-1}\right), \mathrm{C}_{\mathrm{eq}}$ is the equilibrium bacterial concentration $\left(\times 10^{8}\right.$ cells $\left.\mathrm{g}^{-1}\right), \mathrm{B}$ is both the parameter of the polynomial and the value of the derivative at the point of $\mathrm{C}_{\mathrm{eq}}=0$, and $\mathrm{K}_{\mathrm{ads}}$ is a constant of bacterial adsorption.

The slope of the polynomial at the point $\mathrm{C}_{\text {eq }}$ describing the initial isotherms is shown in diagrams (Fig. 4) as a tangent (straight line) to the initial section of the isotherm. In the studies by Borkowski et al. (2015), the $\mathrm{K}_{\mathrm{L}}$ was used as a measure of the bacterial affinity; however, in our study, such an approach did not always make sense.

Viability test. The viability test was performed according to Szala and Borkowski (2014). Briefly, to analyze the loss of viability, solutions of propidium iodide (PI) $(2 \mathrm{mg} / 0.1 \mathrm{l}, \mathrm{pH}=7.4)$ and acridine orange (AO) $(5 \mathrm{mg} / 0.1 \mathrm{l}, \mathrm{pH}=7.4)$ were prepared in phosphate buffer. In a $100 \mathrm{ml}$ sterile glass bottle (Simax), $10 \mathrm{ml}$ of sterile saline solution $(0.9 \% \mathrm{NaCl})$ and $40 \mathrm{mg}$ of the investigated nanomaterials were added. Subsequently, $1 \mathrm{ml}$ of $P$. putida or S. aureus inoculum (approximately $10^{8}$ colony-forming units $(\mathrm{cfu}) / \mathrm{ml}$ in $0.9 \% \mathrm{NaCl}$ ) was added to the mixture and mixed for $120 \mathrm{~min}$ at $25^{\circ} \mathrm{C}$ (200 rpm). Then, the suspension was mixed with sucrose $(60 \%)$ in order to separate of unadsorbed bacteria. After centrifugation, the residuum was stained. Next, ten representative fluorescence images of cells adsorbed onto the surface of aggregates of the nanostructures were acquired using an epifluorescence microscope with a B-filter. The results of the microscopic analysis were expressed as the ratio of the number of cells stained with PI (red-orange) divided by the number of cells stained with PI plus cells stained with AO (green).

Statistical analysis. The obtained data (viability test) were analyzed for significant mean differences using one-way analyses of variance (ANOVA) at $\mathrm{p}<0.05$. Post hoc tests for pair-wise differences and the identification of homogeneous subgroups were conducted using Tukey's HSD procedure. Homogenous subgroups are indicated by diagrams marked by the same lower case letters. The ANOVA was computed with Statistica 10 software (StatSoft. Inc. Tulsa, OK, USA). 


\section{Results and Discussion}

SEM images of commercial SiC (Fig. 1A) showed that the powder contained irregular polygonal grains with sharp edges, with dimensions of about 100-200 $\mu \mathrm{m}$. The graphite that was used as a reference (Fig. 1B) had irregular particle sizes of about $1 \mu \mathrm{m}$. The TiC obtained with the SHS method (Fig. 1C) formed rod-like particles with dimensions of about $50 \times 150 \mathrm{~nm}$. The TiC/C composite (Fig. 1D) was built from spheroidal agglomerates with diameters of about 5-100 $\mu \mathrm{m}$, but the spheroids were built from nanometric particles. Silicon carbide nanorods (Fig. 1E) obtained by the combustion method have dimensions $500 \times 1000 \mathrm{~nm}$. NFSiC
(Fig. 1F) were $10-100 \mathrm{~nm}$ in diameter and were over many micrometers in length. The PZC of the materials is presented in Table I. Examples of mass titration curves are presented in Fig. 2. The materials had different PZC values. The PZC values for the $\mathrm{SiC}$ materials ranged from 2.7 to 3.5 , and in neutral $\mathrm{pH}$, the surface charge of the investigated $\mathrm{SiC}$ materials was negative. For TiC and graphite, the PZCs were 7.2 and 9.4, respectively; thus, at neutral $\mathrm{pH}$, their surface charge is close to zero or positive, respectively.

The isoelectric point of the bacteria used in the presented studies was 2.8 and 3.4 for P.putida and S. aureus, respectively (Table I). This indicates that the surface charge of P.putida was negative at each $\mathrm{pH}$,
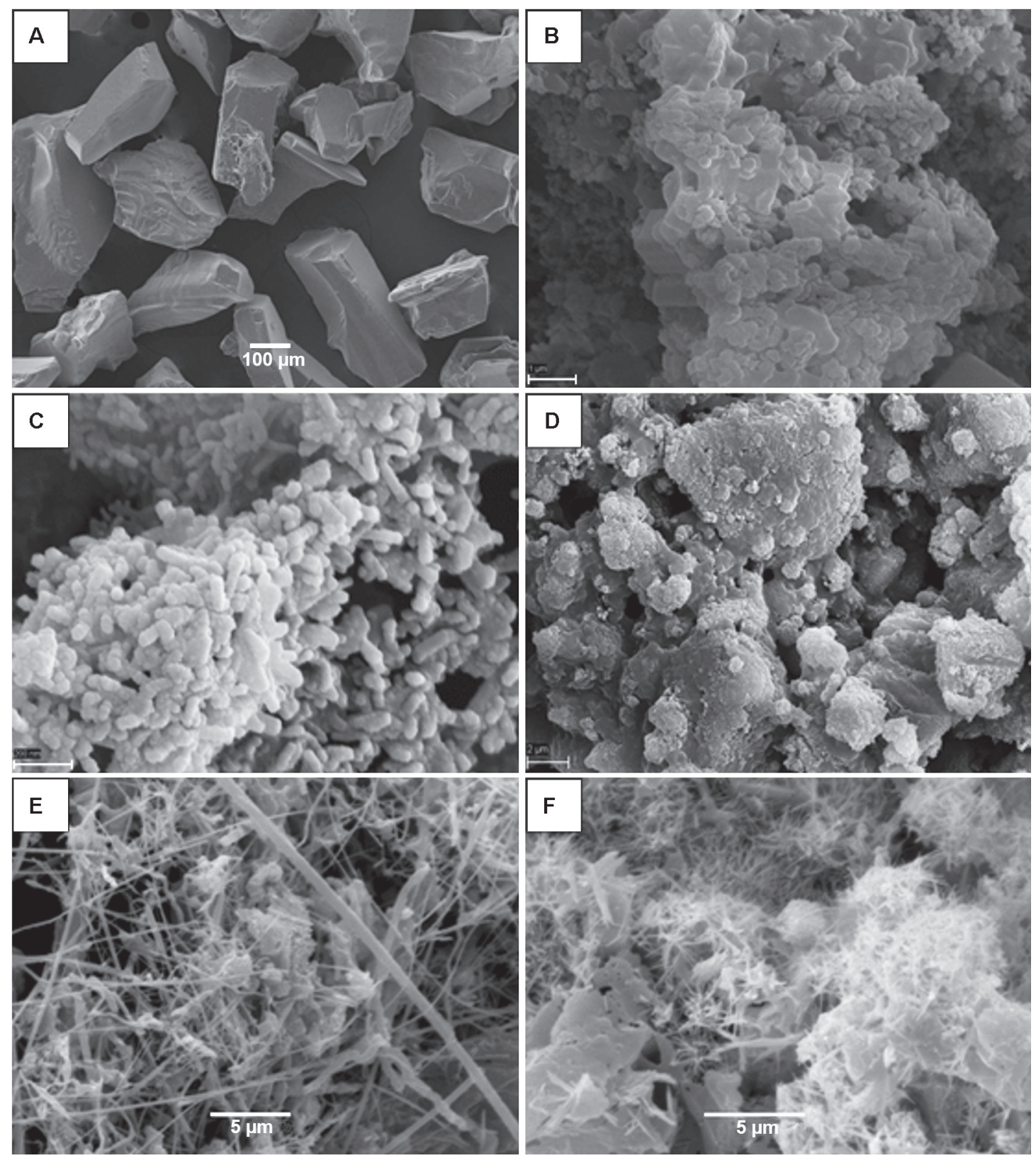

Fig. 1. Ceramic materials used in the studies.

A - $\mu \mathrm{mSiC}$ used as reference material, B - graphite, C - titanium carbide (TiC), D - titanium carbide with graphite (TiC/C), E - nanofibers of silicon carbide (NFSiC), F - nanorods of silicon carbide (NRSiC). 
Table I

The point of zero charge of materials used in the studies

\begin{tabular}{|c|c|c|c|c|c|c|c|c|}
\hline & $\mu \mathrm{mSiC}$ & graphite & $\mathrm{TiC}$ & $\mathrm{TiC} / \mathrm{C}$ & $\mathrm{NRSiC}$ & $\mathrm{NFSiC}$ & P.putida & S. aureus \\
\hline PZC & $2.7^{[1]}$ & $7.5^{[2]}$ & $9.4^{[2]}$ & $7.2^{[2]}$ & $3.5^{[1]}$ & $2.8^{[1]}$ & $2.8^{[1]}$ & $3.4^{[2]}$ \\
\hline
\end{tabular}

${ }^{1}$ Borkowski et al., 2015; ${ }^{2}$ This study

while the surface charge of $S$. aureus was positive at pH 3 and negative at $\mathrm{pH} 6.8$ and 9. Generally, based on the literature, it can be stated that the PZC values for most bacteria are relatively low, ranging from about 2 to 3.5. The charge of the bacterial cell wall originates from the dissociation of acidic groups, such as phosphate, carboxyl, and amino groups (van der Wal et al., 1997).

Adsorption of bacteria. Bacterial adsorption onto the investigated materials, as well as the shape of the isotherms, seemed to depend on the texture of the materials and the species of bacteria. Generally, the adsorption of P. putida was less than than that of S. aureus, and adsorption depended on the $\mathrm{pH}$ of the solution (Fig. 3). Significant adsorption was noted at pH 3 and 6.8; at pH 9, the adsorption was substantially lower. Only in the case of $\mathrm{TiC}$ was this relationship reversed. The adsorption of bacteria onto graphite, $\mathrm{TiC}$, and $\mathrm{TiC} / \mathrm{C}$ were significantly higher at $\mathrm{pH}$ 6.8. The strongest adsorption of $P$. putida (70\%) and S. aureus (90\%) was found for $\mathrm{NRSiC}$ at $\mathrm{pH} 3$ and graphite at $\mathrm{pH} 6.8$, respectively.

The isotherms confirmed the data presented above. Generally, the adsorption isotherms of P.putida reflected its lower adsorption compared with S. aureus (Fig. 4). The shapes of isotherms were similar to the Langmuir and Freundlich functions, but in the case of $\mathrm{TiC}$, the

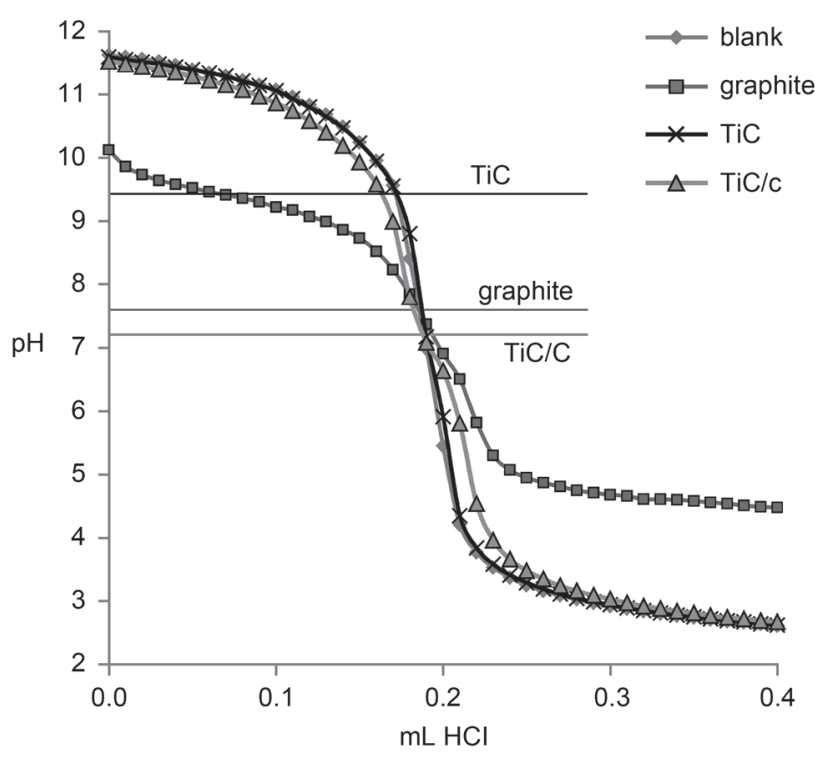

Fig. 2. Example of mass titration curves.

The measurement was realized according to Bourikas et al., (2003). Straight lines represent the point of intersection with blank titration curve. shape was different, indicating multilayer sorption or aggregation of the cells with $\mathrm{TiC}$. It is important to note that the shape of the isotherms was very similar for both bacteria and that only the TiC seemed to interact differently with the bacteria. In the presented figures, straight lines were plotted tangentially to the initial fragment of the isotherms at $\mathrm{C}_{\mathrm{eq}}=0$. These lines represent the adsorption constant $\left(\mathrm{K}_{\mathrm{ads}}^{\mathrm{q}}\right)$ and the affinity of the bacteria to the investigated materials. The measured affinities (as derivatives of an approximated polynomial function at $\mathrm{C}_{\mathrm{eq}}=0$ ) are presented in Table II. These values indicate a high affinity of $P$. putida for $\mathrm{C}, \mathrm{TiC} / \mathrm{C}$, and NRSiC, a moderate affinity for NFSiC, and a low affinity for $\mu \mathrm{mSiC}$ and $\mathrm{TiC}$. In the case of $S$. aureus, similar results were found, but the measured affinities were much higher, which resulted in a significantly higher adsorption of these bacteria onto the investigated materials. Some authors interpreted the Langmuir constant $\left(\mathrm{K}_{\mathrm{L}}\right)$ as the degree of affinity between the bacteria and the tested materials (Jiang et al., 2007). Therefore, a higher $\mathrm{K}_{\mathrm{L}}$ value indicates a higher affinity of bacteria for the

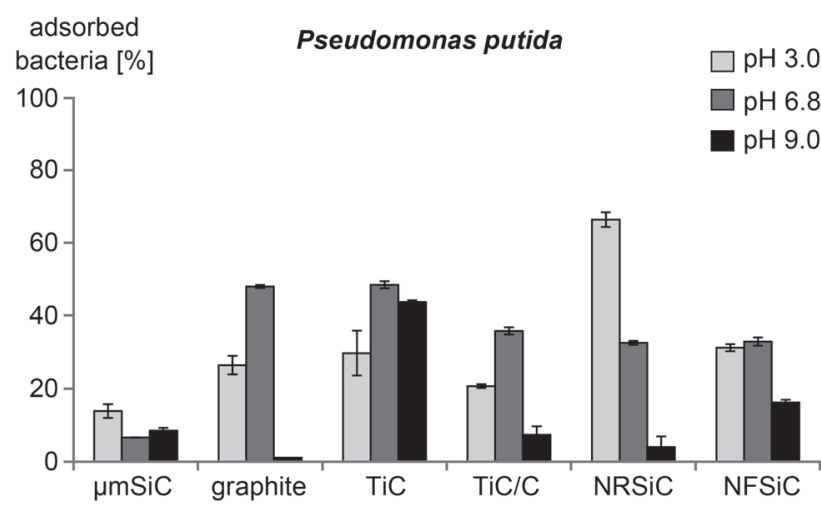

adsorbed
bacteria [\%]

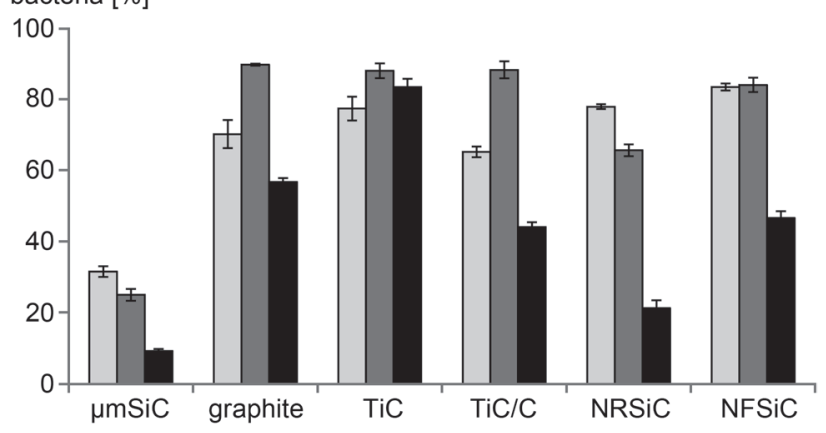

Fig. 3. Adsorption of bacteria P. putida (upper) and S. aureus (lower) onto the investigated materials at different $\mathrm{pH}$. Error bars indicate standard deviations. 

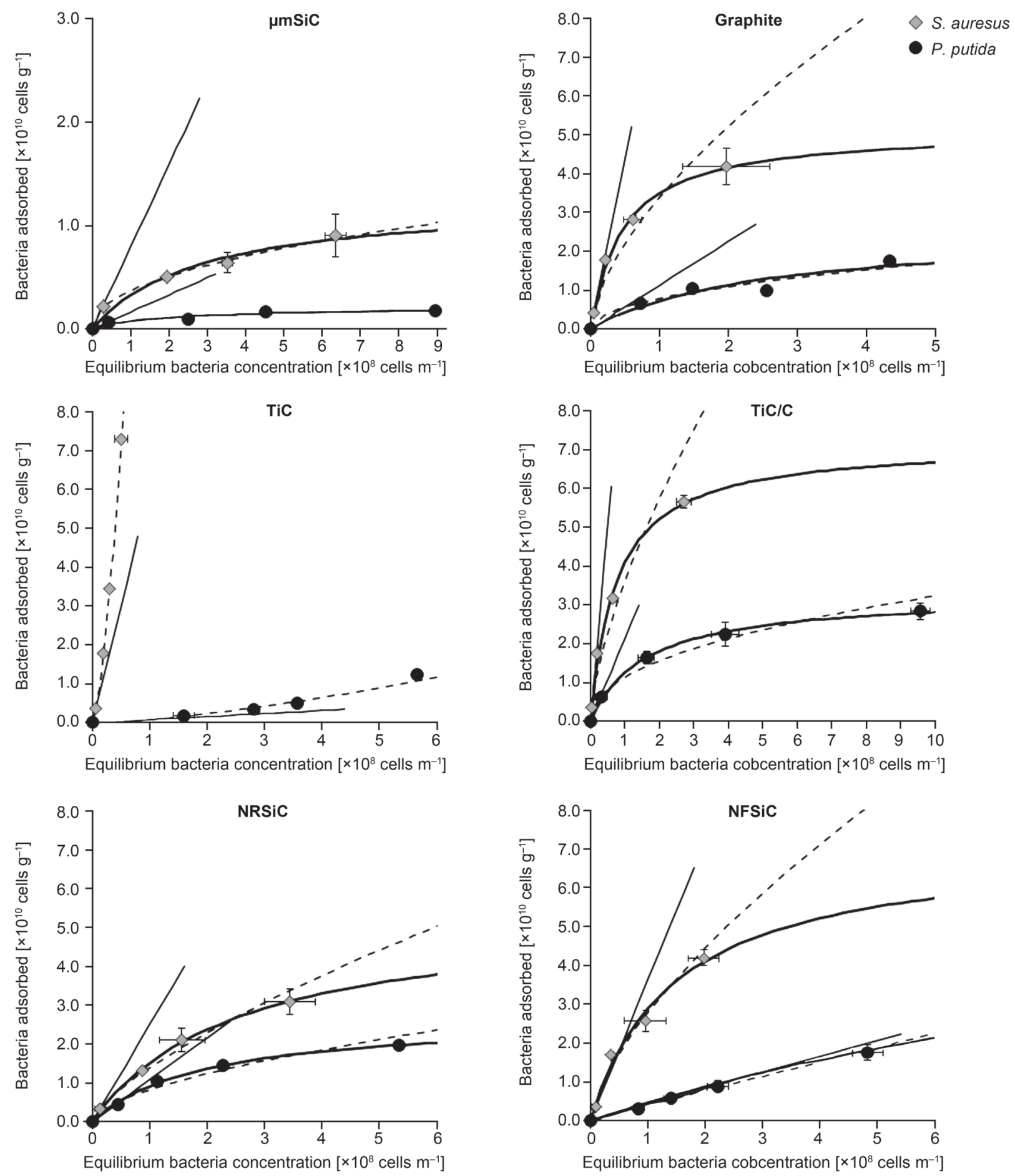

Fig. 4. Isotherms of P. putida and S. aureus adsorption onto investigated materials at $\mathrm{pH} 6.8$.

Symbols represent experimental data, solid curve line - Langmuir model, dashed curve line - Freundlich model, solid straight line is a tangent to polynomial function in $\mathrm{C}_{\mathrm{eq}}=0$. Standard deviation has been marked.

tested materials. Borkowski et al. (2015) showed that the $\mathrm{K}_{\mathrm{L}}$ values for the adsorption of bacteria $P$. putida onto $\mathrm{SiC}$ nanostructures were inversely proportional to $\mathrm{pH}$. This indicates, therefore, a decrease in the affinity of bacteria for the investigated material with increasing $\mathrm{pH}$. In the presented studies, such an approach seems to be insufficient due to the different shapes of the obtained isotherms, especially in the case TiC. Table II allows one to compare the obtained values of $\mathrm{K}_{\mathrm{L}}$ and $\mathrm{K}_{\mathrm{ads}}$. Generally, but not always, a higher value of $\mathrm{K}_{\mathrm{L}}$ corresponds to a higher $\mathrm{K}_{\text {ads }}$. Additionally, sometimes one can come to an incorrect conclusion when comparing the $\mathrm{K}_{\mathrm{L}}$ values for the adsorption of both bacteria. For instance, based on $\mathrm{K}_{\mathrm{L}}$, the affinity of $P$. putida for $\mu \mathrm{mSiC}$ was greater than that of $S$. aureus. Similar results were observed for NRSiC, but the $\mathrm{K}_{\mathrm{ads}}$ showed an inverse 
Table II

Parameters of Langmuir isotherms of bacteria adsorption at pH 6.8 and the constant of bacteria adsorption as a value of the derivative of polynomial at a point of $\mathrm{C}_{\mathrm{eq}}=0$

\begin{tabular}{|l|c|c|c|c|c|c|}
\hline & \multicolumn{3}{|c|}{ P.putida } & \multicolumn{3}{c|}{ S. aureus } \\
\cline { 2 - 7 } & $\begin{array}{c}A_{\mathrm{m}} \\
{\left[\times 10^{10} \mathrm{cells} \mathrm{g}^{-1}\right]}\end{array}$ & $K_{\mathrm{L}}$ & $\mathrm{K}_{\text {ads }}$ & $\begin{array}{c}A_{\mathrm{m}} \\
{\left[\times 10^{10} \mathrm{cells} \mathrm{g}^{-1}\right]}\end{array}$ & $K_{\mathrm{L}}$ & $\mathrm{K}_{\text {ads }}$ \\
\hline$\mu \mathrm{mSiC}$ & 0.22 & 0.52 & 0.17 & 1.25 & 0.35 & 0.79 \\
\hline graphite & 2.57 & 0.40 & 1.12 & 5.12 & 2.16 & 8.65 \\
\hline $\mathrm{TiC}$ & - & - & 0.08 & - & - & 5.99 \\
\hline $\mathrm{TiC} / \mathrm{C}$ & 3.25 & 0.63 & 2.14 & 7.17 & 1.33 & 10.1 \\
\hline NRSiC & 2.55 & 0.53 & 1.08 & 5.41 & 0.39 & 2.50 \\
\hline NFSiC & 7.32 & 0.07 & 0.41 & 7.13 & 0.68 & 3.61 \\
\hline
\end{tabular}

$A_{\mathrm{m}}$ - the maximal number of adsorbed bacteria $\left(\times 10^{10} \mathrm{cells}^{-1}\right)$,

$K_{\mathrm{L}}^{\mathrm{m}}$ - the Langmuir constant,

$\mathrm{K}_{\mathrm{ads}}$ - constant of bacteria adsorption - affinity of bacteria to investigated materials.

relationship. A similar problem can arise when analyzing the maximal amount of adsorbed bacteria. It seems that some results can be overestimated because some curves did not reach the equilibrium stage. However, this problem could not be solved by increasing the concentration of bacteria in the experiments due to the possibility of bacterial flocculation (Borkowski et al., 2015). The results of the experiments presented above were confirmed by epifluorescence microscopy (Fig. 5A-E). The selected pictures present bacteria attached to the investigated materials. These images were obtained for preparations of bacteria and materials in aqueous suspensions; hence, the bacteria and the materials did not form aggregates due to the drying of the suspension on the microscopic slides. It can be stated that the bacteria, both Gram-positive and Gram-negative, can adsorb onto aggregates of graphite, $\mathrm{TiC}$, or $\mathrm{SiC}$ nanostructures. Bacteria were also observed to adsorb onto micrometric $\mathrm{SiC}$, but the adsorption values were significantly lower. Based on the results, it seems that the adsorption of bacteria strongly depends on the texture of the materials, and partially on $\mathrm{pH}$. In the case of NRSiC, NFSiC, and $\mu \mathrm{mSiC}$, the adsorption of bacteria was inversely proportional to $\mathrm{pH}$ generally. Adsorption could be only partially related to the isoelectric points of the bacteria and $\mathrm{SiC}$, as was presented by Borkowski et al. (2015) for P. putida. Some authors emphasize the importance of the isoelectric points of bacteria and mineral materials in the aggregation process. In the paper by Ams et al. (2004), the adsorption of Gram-positive B. subtilis and Gram-negative Pseudomonas mendocina onto the surface of Fe-oxyhydroxide-coated and uncoated quartz grains as a function of $\mathrm{pH}$ was studied. Adsorption appeared to be controlled by the surface charges of the bacteria and the mineral surface. The possibility of bacterial adsorption onto the surface of nanostructures has been presented, e.g., in the work of Kang et al. (2007) and Singh et al. (2011). Similarly, the ability to create a biofilm and the adsorption of bacterial cells onto the surface of mineral materials, including carbon materials and modified clay minerals, were also demonstrated (Yee et al., 2000; Rivera-Utrilla et al., 2001; Yamamoto et al., 2001; Jiang et al., 2007; Rong et al., 2008). These studies also indicated the important roles of $\mathrm{pH}$ and the ionic strength of the solution as significant factors affecting the adsorption of bacterial cells onto the surface of minerals. In the case of the experiment with $\mathrm{SiC}$ and bacteria presented in this paper, the PZC value does not explain the observed phenomena sufficiently. On the contrary, the PZC values seem to affect adsorption to $\mathrm{TiC}, \mathrm{TiC} / \mathrm{C}$, and graphite. In these cases, the adsorption of both P. putida and S. aureus was strongest at neutral $\mathrm{pH}$. For instance, the isoelectric point of graphite was about 7.5, and taking into account the PZC of the bacteria, the adsorption should be strongest at a neutral or slightly acidic pH. At $\mathrm{pH} 9$, the charges of both the bacteria and graphite are negative. At $\mathrm{pH} 3$, the surface charge is positive, and only at a more neutral $\mathrm{pH}$ is the electrostatic effect the strongest. A similar relationship was found in case of adsorption to $\mathrm{TiC} / \mathrm{C}$ and TiC. The PZC of TiC was about 9.4, and even at $\mathrm{pH}$ 9, adsorption should be significant. The obtained results showed that at $\mathrm{pH} 9, \mathrm{TiC}$ formed aggregates with bacteria and behaved as the strongest adsorbent among the investigated materials.

The presented results showed the stronger adsorption of S.aureus compared with P.putida. Both the $\mathrm{A}_{\mathrm{m}}$ and $\mathrm{K}_{\mathrm{ads}}$ showed that $S$. aureus can aggregate with materials more effectively than Gram-negative bacteria, but the shape of the obtained isotherms was quite similar in both cases. Ams et al. (2004) showed that the differences in the adsorption of B. subtilis and P. mendocina onto some mineral phases can be explained by differences in their electrostatic properties and cell wall structures. Generally, in the presented studies, the isotherms were approximated by the Langmuir and 

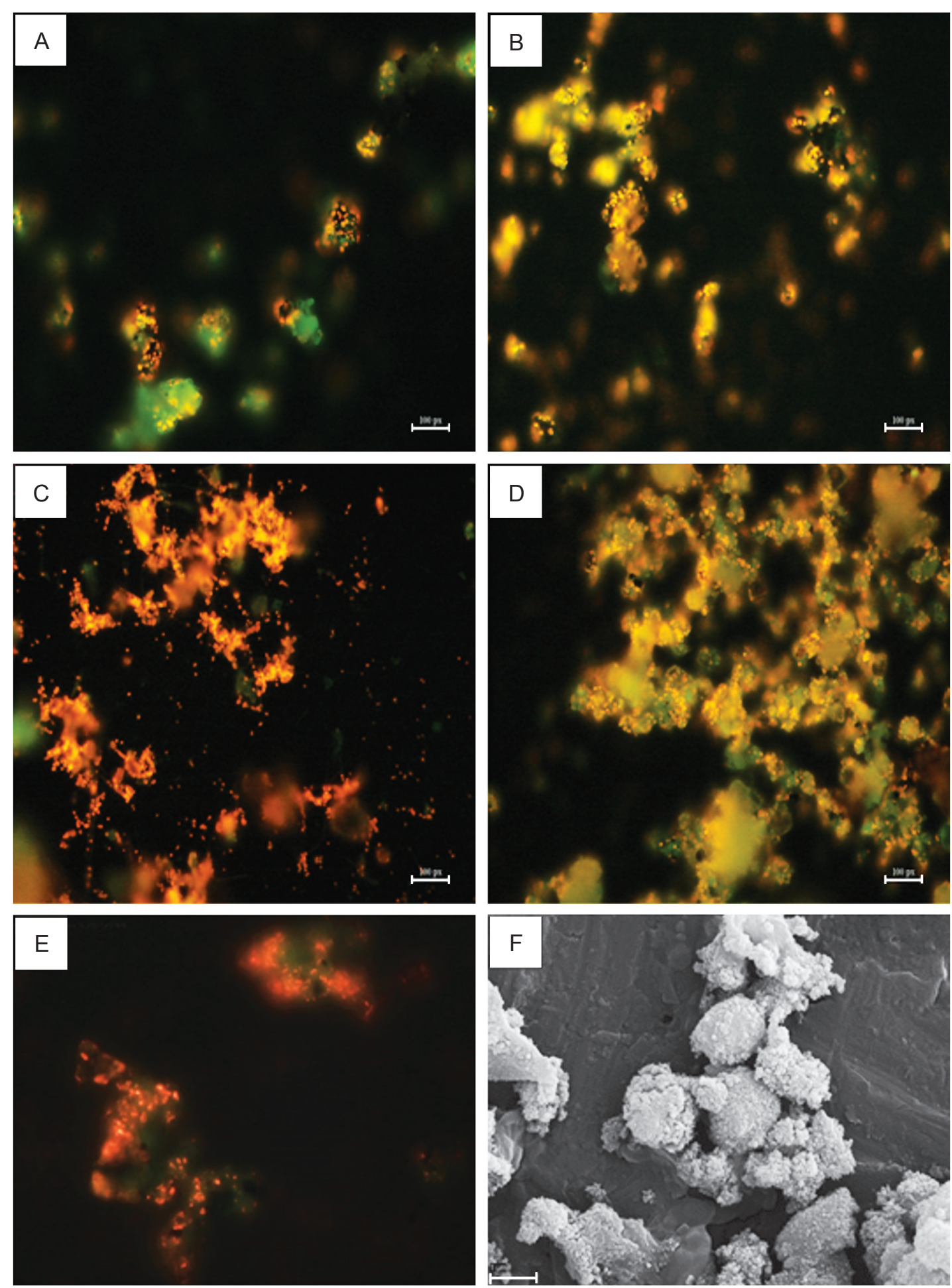

Fig. 5. Bacteria adsorbed onto the investigated materials.

A - S. aureus on graphite; B - S. aureus on TiC/C; C and D - S. aureus on NFSiC and NRSiC respectively; E - P. putida on NRSiC. Bacteria are orange, mineral phases are green. Bars indicate $100 \mu \mathrm{m}$. Pictures E - 600x. F - Probably the bacteria P.putida and TiC particles associated into aggregations after the adsorption experiment. SEM, bar indicates $1 \mu \mathrm{m}$.

Freundlich equations, except for the isotherms obtained with TiC. In this case, the Langmuir isotherm did not make any physical sense, and the shape of the isotherm indicated a multilayer adsorption. It is interesting that these phenomena were observed for both of the investigated bacteria. It seems that $\mathrm{TiC}$ particles did not form aggregates in aqueous suspension, and the bacteria did not adsorb to the surfaces of $\mathrm{TiC}$. It is possible that cells and $\mathrm{TiC}$ particles form aggregates together, and, as a heavier structure, they are easy to separate from free cells in the applied procedure. The SEM images (Fig. 5F) revealed that the bacteria formed structures 
surrounded by $\mathrm{TiC}$ particles, but it cannot be stated that the observed structures are truly aggregates that consist of cells and TiC.

Viability test. The viability test was presented in Figure 6. Based on the measurements, generally it can be stated that $P$. putida cells were more sensitive to the investigated nanomaterials than $S$. aureus cells. The maximum loss of viability was noted in the case of bacteria adsorbed onto NRSiC and NFSiC aggregates. The values reached $90 \%$ and $80 \%$, respectively. The other materials did not exhibit such strong antimicrobial activity in relation to the control and reference material $(\mu \mathrm{mSiC})$. Completely different values were found for $S$. aureus. The maximum loss of viability for bacterial cells adsorbed onto $\mathrm{NRSiC}$ and $\mathrm{TiC} / \mathrm{C}$ reached about $30 \%$ and $15 \%$, respectively. In other cases, the measured values did not differ statistically from the control. Many recent studies focused on the antimicrobial activity of carbon nanostructures, such as single- and multiwalled nanotubes (Kang et al., 2007; Kang et al., 2008a; 2008b; Akhavan et al., 2011; Su et al., 2013) or other carbon materials, such as graphite, graphene, and fullerene (Lyon et al., 2006; Akhavan and Ghaderi, 2010; Liu etal., 2011). The mechanism proposed to explain the antibacterial properties of these materials is primarily based on oxidative stress and the physical interactions with the cell membrane (Liu et al., 2011). Physical interactions with the cell membrane leading to the loss of integrity have been proposed as a key antibacterial mechanism of carbon nanotubes. It is possible that the same mechanism could play a crucial role in the effects of NFSiC and NRSiC on Gram-negative bacteria. It is interesting that Gram-positive bacteria, generally, were much more resistant, and the tested materials did not affect cell viability to the same extent as was observed for P. putida. It seems that Gram-positive bacteria, due to the presence of thick layer of murein in their cell walls, were not strongly affected by the tested materials. Gram-negative bacteria also contain murein, but this layer is much thinner and the cells are enveloped by a lipid outer membrane.

\section{Conclusions}

In the presented experiments, we demonstrated that ceramic materials obtained by self-propagating combustion synthesis can efficiently adsorb P. putida and S. aureus. The hypothesis that adsorption depends on the texture of materials was confirmed by comparing the adsorption of bacteria to NFSiC and NRSiC aggregates to $\mu \mathrm{mSiC}$ aggregates.

It can be concluded that Gram-positive bacteria adsorbed more strongly to these materials. It seems that both the PZC value and the texture of the ceramic

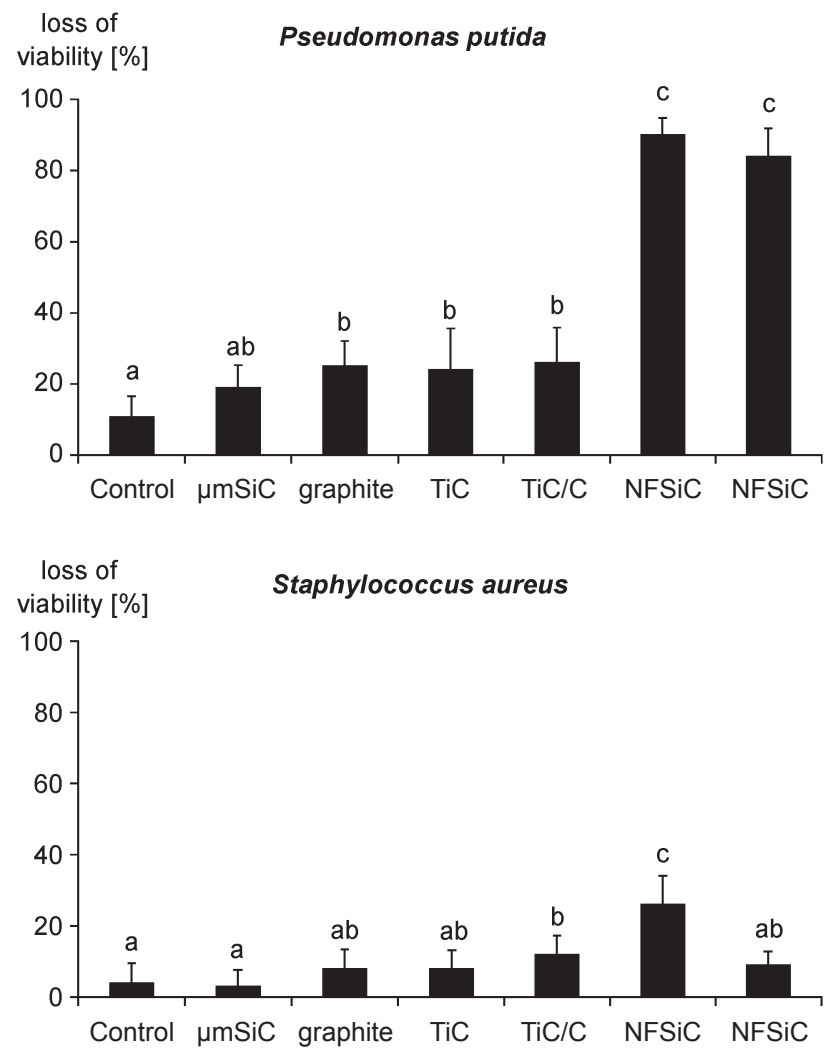

Fig. 6. The loss of viability of bacterial cells adsorbed on the surface of the investigated materials.

The same letters indicate the values do not differ significantly at $\mathrm{p}<0.05$. Error bars indicate standard deviations.

material affected bacterial adsorption. Additionally, on the one hand, Gram-positive bacteria showed a greater adsorption onto the surface of the tested materials. On the other hand, these bacteria had a significantly higher survival rate at the ceramic material surface, probably due to the presence of a thick layer of murein. However, in both cases of the tested bacteria, the greatest toxicity was exhibited by nanorods of $\mathrm{SiC}$.

Based on the obtained results of adsorption and the analysis of the affinity of the bacteria, the investigated materials can be ordered from the largest to smallest sorption capacity, as can the affinity of the bacteria for the tested materials. For P. putida, the following order of the sorption capacity of the materials was observed: $\mathrm{NFSiC}>\mathrm{TiC}>\mathrm{TiC} / \mathrm{C}>$ graphite $>\mathrm{NRSiC}>\mu \mathrm{mSiC}$. In regard to bacterial affinity, the tested materials can be ordered as follows: $\mathrm{TiC} / \mathrm{C}>$ graphite $>\mathrm{NRSiC}>\mathrm{NFSiC}$ $>\mu \mathrm{mSiC}>\mathrm{TiC}$. Similarly, for S. aureus, the sorption capacity of the materials was: $\mathrm{TiC}>\mathrm{TiC} / \mathrm{C}>\mathrm{NFSiC}>$ $\mathrm{NRSiC}>$ graphite $>\mu \mathrm{mSiC}$. Regarding bacterial affinity, the materials can be ordered as follows: $\mathrm{TiC} / \mathrm{C}>$ graphite $>\mathrm{TiC}>\mathrm{NFSiC}>\mathrm{NRSiC}>\mu \mathrm{mSiC}$.

These rankings reveal an interesting relationship. On the one hand, the bacterial affinity to $\mathrm{TiC}$ is relatively weak. On the other hand, in dense cell suspensions, $\mathrm{TiC}$ behaves like a very good adsorbent of bacteria. This 
relationship was observed for both tested bacteria. In turn, the mixture of $\mathrm{TiC}$ and graphite $(\mathrm{TiC} / \mathrm{C})$ appears to be a very good adsorbent, and simultaneously, both bacteria exhibited significant affinity for this material.

\section{Acknowledgments}

The research was partially supported by the European Union within European Regional Development Fund, through grant Innovative Economy (POIG.02.02.00-00-025/09) and by the Faculty of Geology, University of Warsaw, BST 166901/2013. The authors thank the Reviewers for their critical remarks and comments which have improved this article.

\section{Literature}

Akhavan O. and E. Ghaderi. 2010. Toxicity of graphene and graphene oxide nanowalls against bacteria. ACS Nano 4: 5731-5736. Akhavan O., M. Abdolahad, Y. Abdi and S. Mohajerzadeh. 2011. Silver nanoparticles within vertically aligned multi-wall carbon nanotubes with open tips for antibacterial purposes. J. Mater Chem. 21: 387-393.

Ams D.A., J.B. Fein, H. Dong and P.A. Maurice. 2004. Experimental measurements of the adsorption of Bacillus subtilis and Pseudomonas mendocina onto Fe-oxyhydroxide-coated and uncoated quartz grains. Geomicrobiology J. 21: 511-519.

Barillet S., A. Simon-Deckers, N. Herlin-Boime, M. MayneL'Hermite, C. Reynaud, D. Cassio, B. Gouget and M. Carrière. 2010. Toxicological consequences of $\mathrm{TiO}_{2}, \mathrm{SiC}$ nanoparticles and multi-walled carbon nanotubes exposure in several mammalian cell types: an in vitro study. J. Nanopart Res. 12: 61-73.

Borkowski A., M. Szala and T. Clapa. 2015. Adsorption studies of the Gram-negative bacteria onto nanostructured silicon carbide. Appl. Biochem. Biotechnol. 175: 1448-1459.

Bourikas K., J. Vakros, C. Kordulis and A. Lycourghiotis. 2003. Potentiometric mass titrations: experimental and theoretical establishment of a new technique for determining the point of zero charge (PZC) of metal (hydr)oxides. J. Phys. Chem. B. 107: 9441-9451.

Cadet J.T., T. Delatour, D. Douki, J. Gasparutto, J. Pouget, S. Ravanat and S. Sauvaigo. 1999. Hydroxyl radicals and DNA base damage. Mutat Res. 424: 9-21.

Cudziło S., M. Szala, A. Huczko and M. Bystrzejewski. 2007. Combustion reactions of poly(carbon monofluoride), (CF)n with different reductants and characterization of products. Propellants, Explosives, Pyrotechnics 32: 149-154.

Farre M., K. Gajda-Schrantz, L. Kantiani and D. Barcelo. 2009. Ecotoxicity and analysis of nanomaterials in the aquatic environment. Anal. Bioanal. Chem. 393: 81-95.

Fenoglio I., M. Tomatis, D. Lison, J. Muller, A. Fonseca, B.J. Nagy and B. Fubini. 2006. Reactivity of carbon nanotubes: free radical generation or scavenging activity? Free Radic. Biol. Med. 40: 1227-1233.

Hossain F., O.J. Perales-Perez, S. Hwang and F. Roman. 2014 Antimicrobial nanomaterials as water disinfectant: applications, limitations and future perspectives. Sci. Total Environ. 466-467: 1047-1059.

Huczko A., M. Bystrzejewski, H. Lange, A. Fabianowska, S. Cudziło, A. Panas and M. Szala. 2005. Combustion synthesis as a novel method for production of 1-D SiC nanostructures. J. Phys. Chem. B. 109: 16244-16251.

Jiang D., G. Huang, P. Cai P, X. Rong, and W. Chen. 2007. Adsorption of Pseudomonas putida on clay minerals and iron oxide. Coll. Surf. B: Biointerf. 54: 217-221.
Joseph L., J.R.V. Flora, Y.G. Park, M. Badawy, H. Saleh and Y. Yoon. 2012. Removal of natural organic matter from potentia drinking water sources by combined coagulation and adsorption using carbon nanomaterials. Separation and Purification Technology. 95: 64-72.

Kang S., M. Pinault, L.D. Pfefferle L.D and M. Elimelech. 2007. Single-walled carbon nanotubes exhibit strong antimicrobial activity. Langmuir. 23: 8670-8673.

Kang S., M. Herzberg, D.F. Rodrigues and M. Elimelech. 2008a. Antibacterial effects of carbon nanotubes: size does matter. Langmuir 24: 6409-6413.

Kang S., M.S. Mauter and M. Elimelech. 2008b. Physicochemica determinants of multiwalled carbon nanotube bacterial cytotoxicity. Environ. Sci. Technol. 42: 7528-7534.

Li Q., S. Mahendra, D.Y. Lyon, L. Brunet, M.V. Liga, D. Li and P.J.J. Alvarez. 2008. Antimicrobial nanomaterials for water disinfection and microbial control: potential applications and implications. Water Res. 42: 4591-4602.

Liu S., T.H. Zeng, M. Hofmann, E. Burcombe, J. Wei, R. Jiang, J. Kong and Y. Chen. 2011. Antibacterial activity of graphite, graphite oxide, graphene oxide, and reduced graphene oxide: membrane and oxidative stress. ACS Nano. 5: 6971-6980.

Lyon D.Y., L.K. Adams, J.C. Falkner and P.J.J. Alvarez. 2006. Antibacterial activity of fullerene water suspensions: effects of preparation method and particle size. Environ. Sci. Technol. 40: 4360-4366. Qu X., P.J.J. Alvarez and Q. Li. 2013. Application of nanotechnology in water and wastewater treatment. Water Res. 47: 3931-3946. Reddy A.R.N., Y.N. Reddy, D.R. Krishna and V. Himabindu. 2010. In vitro cytotoxicity of multi-wall carbon nanotubes on human cell lines. Toxicol. Environ. Chem. 92: 1697-1703.

Rivera-Utrilla J., I. Bautista-Toledo, M.A. Ferro-Garcia and C. Moreno-Castilla. 2001. Activated carbon surface modifications by adsorption of bacteria and their effect on aqueous lead adsorption. J. Chem. Technol. Biotechnol. 76: 1209-1215.

Rong X., Q. Huang, X. He, H. Chen H, P. Cai and W. Liang. 2008. Interaction of Pseudomonas putida with kaolinite and montmorillonite: A combination study by equilibrium adsorption, ITC, SEM and FTIR. Coll. Surf. B Biointerf. 64: 49-55.

Savage N. and M.S. Diallo. 2005. Nanomaterials and water purification: opportunities and challenges. J. Nanoparticle Res. 7: 331-342. Singh A.V., V. Vyas, R. Patil R, V. Sharma, P.E. Scopelliti, G. Bongiorno, A. Podestà A, C. Lenardi, W.N. Gade and P. Milani. 2011. Quantitative characterization of the influence of the nanoscale morphology of nanostructured surfaces on bacterial adhesion and biofilm formation. PLoS ONE 6(9): e25029.

Su R., Y. Jin, M. Tong and H. Kim. 2013. Bactericidal activity of Ag-doped multi-walled carbon nanotubes and the effects of extracellular polymeric substances and natural organic matter. Coll. Surf. B. Biointerf. 104: 133-139.

Szala M. 2010. Hexachloroethane as an efficient oxidizer in combustion synthesis of carbonaceous and ceramic nanostructures. International Journal of Self-Propagating High-Temperature Synthesis 19: 28-33.

Szala M. and A. Borkowski. 2014. Toxicity assessment of SiC nanofibers and nanorods against bacteria. Ecotoxicol. Environ. Saf. 100: 287-293.

van der Wal A., W. Norde, A.J.B. Zehnder and J. Lyklema. 1997. Determination of the total charge in the cell walls of Gram-positive bacteria. Coll. Surf. B: Biointerf. 9: 81-100.

Yamamoto O., K. Nakakoshi, T. Sasamoto, H. Nakagawa and K. Miura. 2001. Adsorption and growth inhibition of bacteria on carbon materials containing zinc oxide. Carbon 39: 1643-1651.

Yee N., J.B. Fein and C.J. Daughney. 2000. Experimental study of the $\mathrm{pH}$, ionic strength, and reversibility behaviour of bacteriamineral adsorption. Geochim. Cosmochim. Acta 64: 609-617. 